\title{
The Relationship Between Predictability and Earnings Volatility: The Case of Companies Listed on the Casablanca Stock Exchange
}

\author{
Khalid El OUAFA $^{1^{*}} \quad$ Haniya Oumaima ERRADOUANI ${ }^{2}$ \\ 1.Professor, management department, Cadi Ayyad University, Morocco \\ 2.PHD student, University of Picardie Jules verne, France
}

\begin{abstract}
The study of the predictability of accounting results is extremely important for investors as well as for the various stakeholders of listed companies. The objective of this work is to study the relationship between the predictability of earnings and their volatility. In principle, the volatility of earnings is supposed to reduce its predictability. However, the existing literature, based on short-term horizon, fails to provide convincing results (Sloan, 1996; Lev and Thiagarajan 1993; Abarnell \& Bushee, 1997). Through this work, we first seek to verify the meaning and intensity of the relationship between predictability and volatility, while applying a standpoint of a long-term study. Then, we check the load of each component of the volatility - accounting component or economic component - on the predictability of earnings. Our results confirm our prediction, ie the presence of a negative relationship between volatility and the predictability of earnings. Nevertheless, this capacity decreases with the presence of the extreme values of earnings
\end{abstract}

Keywords: Predictability; volatility; accounting data; Morocco context.

DOI: $10.7176 /$ RJFA/11-24-10

Publication date: December $31^{\text {st }} 2020$

\section{Introduction}

The economic instability and the aggressive competition are the main features of the current economic context. Its volatility has almost doubled over the last forty years (Givoly and Hayn, 2000). It has also been combined with financial scandals that have affected many multinational firms through accounting manipulations. As a result of all these factors, earnings forecasts have become vulnerable and have prompted both professionals (analysts, investors, etc.) and researchers to deepen their studies on the predictive power of accounting and financial data (net earnings, operating results, EBITDA, cash flows, etc.) and on the factors that have an impact on their relevance, especially their volatility.

According to (Dichev \& Tang, 2009, p161), we are still very limited in terms of knowledge about the predictive power of accounting data. Thus, our work is aligned within this field of research and tries to contribute, in the Moroccan context, to the assessment of the predictive power of accounting data (net income) in a long-term horizon and how it relates to their volatility. In addition, this work represents a sequel to the study on the informational content of accounting data on the Moroccan stock-exchange (El Ouafa, 2017) and provides benchmarks against other studies in different contexts.

The first part will be focused on a review of the literature relating to our study and the formulation of the relevant hypotheses. The second part would provide descriptive statistics of our sample as well as the results of various statistical tests, whilst the last part would conclude.

\section{Theoretical framework and hypotheses}

The literature on the predictive power of accounting and financial data is mainly concerned with short-term horizons (Foster, 1977; Sloan, 1996; Abarbanell \& Bushee, 1997). However, there is a paucity of studies on longterm horizons; for instance, Finger (1994); Penman \& Zhang (2002); Dichev \& Tang (2009), etc. Several recent studies have focused on the relationship between the predictive power of accounting results and their volatility (Minton et al, 2002; Dichev \& Tang, 2009; Frankel \& Litov, 2009; Petrovic et al, 2009; Hamzavi \& Aflatooni, 2011; khodadadi et al, 2012; Cao \& Narayanamoorthy, 2012 Ben Mhamed \& Jilani, 2015). This volatility is due to two main components: the economic component, in other words, because of the economic context (hazards of the activity, economic conjuncture, competition...) and the accounting component (latitude of accounting methods, managerial latitude and manipulation of accounting data...).

Several empirical studies have analyzed the relationship between the volatility of accounting and financial earnings and their predictive power. Graham et al (2005) surveyed 401 financial managers in order to identify key decision factors in determining accounting earnings. They found that $97 \%$ of the respondents were dissatisfied with the volatility of earnings and preferred earnings smoothing. This aversion to volatility is mainly due to its negative impact on the predictive power of earnings ( $80 \%$ of the responses).

A number of empirical studies confirmed the existence of a negative relationship between the predictive power of accounting earnings and their volatility (Dichev and Tang, 2009; Petrovic et al., 2009). Dichev and Tang, 2009 assumed that a linear relationship exists between future and current accounting earnings. Thereafter, they 
formed quintiles based on earnings volatility level. The authors found that the correlation coefficient, which also informs about the predictive power of the earnings, decreases gradually (from 0.93 to 0.51 ) as their volatility increases. These results have also been reconfirmed by Frankel \& Litov (2009) who proceeded to the same test while adding several control contexts.

Furthermore, several studies have looked at the relationship between volatility and predictive power within the framework of under- or over-investment assumption. For instance, putting forward the hypothesis of underinvestment, Smith \& Stulz (1985) and Froot and al (1993) have found that the current level of volatility is inversely linked to the future performance of cash flows. Minton and Shrand (1999) argue that earnings volatility reduces the average value of investments over a six-year period, leading to a lower generating capacity of cash flows (earnings), only for firms with low cash flows (earnings).

Petrovic and al (2009) analyze the relationship between the ex-ante volatility of accounting results and their future performance. They conclude that ex-ante earnings volatility is inversely linked to the future expected earnings and this correlation is even stronger for firms with high earnings levels. This finding is explained by the authors using the hypothesis of under or over-investment. This means that in periods of high volatility, the lack of liquidity increased as well as uncertainty, thus raising the cost of capital. More recently, Ben Mhamed \& Jilani, (2015) found a negative correlation between earnings volatility and predictive power for a sample of Canadian companies over the period [2006-2011]. Their finding also confirms that predictive power becomes important for firms with high earnings levels.

We adopt the mathematical development used by Dichev and Tang (2009), which is the basis of our analysis. The authors assume the following autoregressive relationship:

$$
\text { Earningt }=\alpha+\beta \text { earningt }-1+\varepsilon
$$

The variance of each component corresponds to:

$$
\operatorname{Var}(\text { Earningt })=\beta 2(\text { Earningt-1 })+\operatorname{Var}(\varepsilon)
$$

If we consider that the variance of the results is steady in our study horizon, we get:

$$
\operatorname{Var}(\varepsilon)=\operatorname{Var}(\text { Earningt }) *(1-\beta 2)
$$

Equation (3) is the basis of the assumed negative link between volatility and the predictive power of earnings. Thus, Var (Earningt) is the representative variable of earnings volatility. The $\operatorname{Var}(\varepsilon)$ is the residential variance of the earnings predictive power, it includes the variation of extra-accounting items other than those included in the correlation coefficient $\beta$.

The predictive power represented by $\operatorname{Var}(\varepsilon)$ is absolute and unadjusted for earnings volatility. Therefore, as we are interested by relative volatility, $\operatorname{Var}(\varepsilon)$ 's denominator is $\operatorname{Var}($ Earningt). If we replace it in relation 3, we get:

$$
1-\operatorname{Var}(\varepsilon) / \operatorname{Var}(\text { Earning })=\beta 2
$$

Or, $E^{2}=\beta 2$

This confirms that the relative predictive power is the coefficient of determination squared $\left(\mathrm{E}^{2}\right)$ with a negative link between the predictive power and the earnings volatility. Thus, the analysis of volatility's effect on the importance of correlation enables us to infer its effect on the predictive power.

To sum up, studies that analyze how the volatility of earnings is related to their predictive power confirm that volatility has a negative impact on predictive power. Hence, we are led by the same hypothesis in the context of companies listed on the Casablanca Stock Exchange. This means that the predictive power of accounting results is lower when high volatility is present. In addition, the presence of extreme values (very low or very high) is supposed to be similar to a very high level of information asymmetry and, consequently, a high transitory level of volatility. As such, we expect that the predictive power of accounting results is inversely related to the extent of their value. That is, transitional volatility would be high for extreme values of accounting results and low for moderate values.

\section{Sample and results}

All the information relating to our sample is summarized in Table 1 (Panel A). The sample includes all companies listed on the Main Market of the Casablanca Stock Exchange over the period [2009-2018]. So, after the elimination of companies operating in the financial sector, because of the nature of their activity, the companies whose fiscal years are not in line with the calendar year and the companies for which data are not fully available for the studied period, a total of 480 observations were obtained. The study horizon is 10 years with 48 listed companies from 12 different business sectors.

In this study, the main variable is the net income divided by average assets. Earnings volatility is calculated by using the standard deviation of the last five years. For the purpose of neutralizing the impact of extreme variations, values representing $1 \%$ at the bottom and top have been eliminated from the distribution.

As shown in Table 1, the average result per asset is $6.14 \%$, slightly higher compared to the studies that used the adjusted result for exceptional items (Dichev \& Tan, 2009) with a median of $5.78 \%$. Additionally, earnings volatility, determined using the standard deviation of earnings over the last five years, is $3.63 \%$, which is low compared to other previous studies. Furthermore, there is also a low volatility standard deviation which shows a 
low earnings volatility among the companies, the focus of our study.

\subsection{Short-term predictive power results}

In Table 2 (Panel A), the results refer to the correlation and determination coefficients for equation 1. Using this equation, we can measure the predictive power of the results over a one-year delay. As a result, we get persistence (correlation coefficient) of 0.85 and a coefficient of determination R 2 of 0.65 for the whole sample. The correlation graph (Figure 1) illustrates these results by comparing the results of year $t+1$ with those of year $t$.

Subsequently, data will be classified into five quintiles, based on the volatility of the results. Panel B results show a strong link between the degree of earnings volatility and earnings persistence (correlation). The correlation coefficient increases from 0.95 for the first quintile to 0.74 for the last quintile. This finding shows that as we move from a low-volatility quintile to a high-volatility quintile, the predictive power of the earnings decreases. This means that earnings volatility has a negative effect on its predictive power (or persistence). This result is also verified by the auto-correlation test of the volatility and the result, which showed a negative correlation coefficient $(-0.385)$ and significant at a threshold of $5 \%$. Finally, statistical tests on the differences in predictive power and $\mathrm{R} 2$ between the first and last quintile are highly significant $(\mathrm{P}<0.001)$.

Panel B (Table 2) presents the results of the quintile tests ranked according to the results values. The aim is to create categories or quintiles of results on the basis of their value (moderate or extreme). In this way, first of all, the results are classified in increasing decile order. Then, the quintiles are established: quintile 5 is made up of the two deciles 1 and 10, quintile 4 is made up of deciles 2 and 9 , and so on. Panel C (Table 2) shows that the predictive power of the results decreases as the range of the results diminishes. In this test, it is expected to show that the extreme values of the results have a low predictive power compared to moderate values. This means that quintile 5 should report lower predictive power than quintiles 4, 3,2 and 1. However, the results show the opposite, that is, the extreme values of the results have higher predictive power. Correlation coefficients went from 1.08 for quintile 5 to 0.09 for quintile 1 . Likewise, the determination coefficients went from 0.75 for quintile 5 to 0.11 for quintile 1.

\subsection{Long-term predictive power results}

In this section, the focus is on the study of the predictive power of accounting results over a long-term horizon (1 to 5 years). The results presented in table 3 (panel A) relate to the predictive power of our sample as a whole. It shows that the predictive power decreases over time, which means that as the time horizon increases, the predictive power expressed by the correlation coefficient decreases. This coefficient went from 0.83 for a prediction horizon of one year to 0.58 for a prediction horizon of 5 years. Equally, the determination coefficient went from 0.64 to 0.32 .

In order to measure the impact of volatility on long-term predictive power, two extreme quintiles (1 and 5) were formed on the basis of the volatility of results (Table 3, panel B). For the first quintile, with low volatility, the results show a very high predictive power over all horizons. It ranges from 0.92 for one prediction year to 0.86 for a horizon of 5 prediction years. Respectively, the coefficient of determination goes from 0.90 to 0.78 .

The results for the last quintile (Table 3, Panel C), characterized by a high degree of volatility, show that the predictive power is significantly lower than the one found for the first quintile. The correlation coefficient ranges from 0.83 for a one-year prediction horizon to 0.52 for a 5 -year prediction horizon. This confirms our initial prediction as well as the results of other studies, which means that the earnings volatility has a negative impact on their predictive power. Additionally, the predictive power decreases progressively as the study horizon increases.

When studying the impact of the economic component of volatility in the results, we split our sample into two parts: the business sector and, the volatility quintile to which each company belongs. According to table 4 , the results show that, excluding the electrical industry sector, the other sectors are randomly spread with regard to the degree of their volatility. We can therefore conclude that the volatility of the results is mainly explained by the volatility of their accounting component compared to their economic component.

To sum up, the results of this study confirm that the earnings volatility decreases their predictive power and confirm the findings obtained in other contexts (American, Canadian...). In contrast to our prediction, extreme values have a higher predictive power than moderate values. Further, the impact of the industry on earnings volatility seems insignificant.

\section{Conclusion}

The purpose of our study is to analyse the link between earnings volatility and their predictive power. It focuses on the predictive power of accounting data. These studies have been attracting researchers and practitioners since the early 2000s, due to instability, volatility and lack of visibility of the current economic context. We have found that the results of our study confirm those observed in other contexts (Dichev \& Tang 2009; Cao \& Narayanamoorthy, 2012; Ben Mhamed \& Jilani, 2015), that is, volatility has a negative impact on the earnings predictability. However, our results show that extreme values of earnings have a low predictive power. 
As with other studies, we face some methodological limits in our work. These mainly relate to the number of companies studied, only 48 companies and to the variable studied, in this case net earnings. The variable includes exceptional accounting items that may affect earnings volatility. Nevertheless, our study is the first, to be carried out in the Moroccan context, which focuses on the relationship between volatility and the predictability of accounting data. This study will certainly pave the way for several studies on the predictability of other accounting data (EBITDA, operating income, etc.) and financial data (cash flows, etc.) in different contexts, on their quality or their impact on stock market performance...

\section{References}

Abarbanell, J. et Victor, B. (1992). "Tests of analysts' overreaction/underreaction to earnings information as an explanation for anomalous stock price behavior". The Journal of Finance 47, 1181-1207.

Abarbanell, J. et Bushee, B. (1997). "Fundamental analysis, future earnings, and stock prices". Journal of Accounting Research, 1-24.

Ben Mhamed, Y. et Jilani, F. (2015). "Earnings Volatility and Earnings Predictability”. Journal of Business Studies Quarterly, Volume 6, Number 3, 36-53.

Cao S.S. et Narayanamoorthy G.S. (2012). "Earnings volatility, Post-Earnings Anouncement

Drift and Trading Frictions", Journal of Accounting Research, Vol.50, n¹, 41-74.

Dichev I.D. et Tang V.W. (2009). "Earnings volatility and earnings predictability", Journal of Accounting and Economics, Vol.47, 160-181.

El Ouafa, K. (2017). "Information Content of Annual Earnings Announcements: Evidence from Moroccan Stock Market", Research Journal of Finance and Accounting, Vol. 8, No. 14, 2017, 49- 56.

Frankel. R. et Litov L. P. (2009). "Earnings Persistence”, Journal of Accounting and Economics, Vol.47, 182-190.

Foster G. (1977). "Quarterly accounting data: time-series properties and predictive-ability results", The Accounting Review, Vol.52, 1-21.

Finger, C. A. (1994). "The ability of earnings to predict future earnings and cash flows", Journal of Accounting Research, Vol 32, 210-223.

Froot K., Scharfstein D. et Stein J. (1993). "Risk Management: Coordinating Investment and Financing Policies", Journal of Finance, Vol.48, 1629-1658.

Graham J., Campbell H. et Rajgopal S. (2005). "The economic implications of corporate financial reporting", Journal of Accounting and Economics, Vol.40, 3-73.

Givoly, D. et Hayn C. (2000). "The changing time-series properties of earnings, cash flows and accruals: Has financial reporting become more conservative", Journal of Accounting and Economics, 29, 287-320.

Hamzavi M.A. et Aflatooni A. (2011), "Earnings Smoothing and Earnings Predictability", Business Intelligence Journal, 187-201.

Khodadadi V., Tamjidi N., Fazeli Y.S. et Hushmandi K.B. (2012). "Earnings Predictability and its Components Volatility", International Reserch Journal of Finance and Economics, Vol.86, 72-85.

Lev, B., et Thiagarajan, S. R. (1993). "Fundamental information analysis", Journal of Accounting Research, 31 (2), 190-215.

Minton B. et Schrand C. (1999). "The Impact of Cash Flow Volatility on Discretionary Investment and the Costs of Debt and Equity Financing”, Journal of Financial Economics, Vol. 54, n³, 432-60.

Minton B., Schrand C. et Walther B. (2002), "The Role of Volatility in Forecasting", Review of Accounting Studies, Vol. 7, 195-215.

Penman, S. H. et Zhang, X. (2002), "Accounting conservatism, the quality of earnings, and stock returns", The Accounting Review, 77 (2), 237-264.

Petrovic N., Manson S. et Coakley J. (2009), “ Does Volatility Improve UK Earnings

Forecasts?", Journal of Business Finance \& Accounting, Vol.36, n9-10, 1148-1179.

Smith, C. et Stulz, R. (1985), “The determinants of firms' hedging policies”, Journal of Financial and Quantitative Analysis, 20(4), 391-406.

Sloan R. (1996), "Do stock prices fully reflect information in accruals and cash flows about future earnings?" The Accounting Review, Vol. 71, 289-316. 


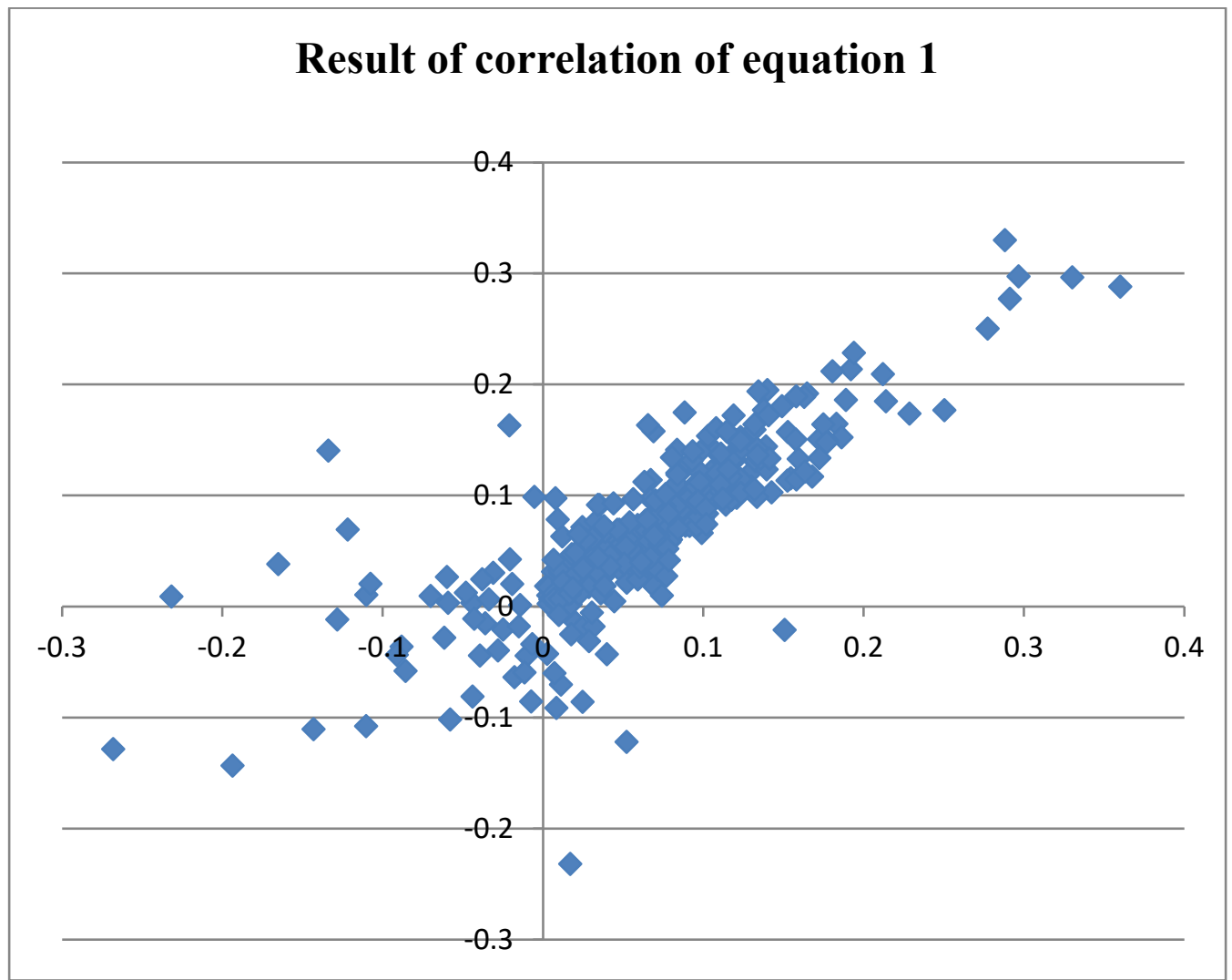

Figure 1: Graph correlation of equation 1

Table 1: Descriptive statistics

Panel A: Distribution of sample firms by industry segment

\begin{tabular}{|l|c|}
\hline \multicolumn{1}{|c|}{ Industry } & Number of Firms \\
\hline Agri-Food & 8 \\
\hline Construction & 5 \\
\hline Chimicals & 2 \\
\hline Transport and Sales & 9 \\
\hline Electric Industry & 3 \\
\hline Metallurgy Industry & 3 \\
\hline Health Care & 2 \\
\hline Manufacturing & 1 \\
\hline Computer services \& software & 1 \\
\hline Energy & 4 \\
\hline Real estate \& Hotel & 3 \\
\hline Information \& telecommunication & 7 \\
\hline & Total \\
\hline
\end{tabular}

Panel B: Variables

\begin{tabular}{|c|c|c|c|c|c|c|}
\hline Variables & Number & Mean & Std Dev & Minimum & Maximum & Median \\
\hline Earnings & 480 & 0,0614 & 0,0729 & $-0,2681$ & 0,3599 & 0,0578 \\
\hline Volatility (earnings) & 480 & 0,0368 & 0,0263 & $-0,2681$ & 0,3599 & 0,0282 \\
\hline
\end{tabular}

Earnings variable is defined as earnings before extraordinary item deflated by average total assets. Volatility of earnings variable is defined as the firm specific volatility of earnings, which is calculated as the standard deviation of Earnings over the most recent 5 years. 
Table 2

Panel A: Results for the earnings persistence regression

\begin{tabular}{|c|c|c|}
\hline \multicolumn{3}{|c|}{ Equation : Earnings $\mathrm{S}_{\mathrm{t}+1}=\alpha+\beta$ Earnings $_{\mathrm{t}}+\varepsilon$} \\
\hline \multirow{2}{*}{ Full Sample } & $\mathrm{B}$ & Adjusted $\mathrm{R}^{2}$ \\
\cline { 2 - 3 } & 0,851 & 0.652 \\
\hline
\end{tabular}

Panel B: Regression results by quintiles of earnings volatility

\begin{tabular}{|c|c|c|}
\hline Quintiles by Earnings Volatility & $\begin{array}{c}\boldsymbol{\beta} \\
\text { (Persistence) }\end{array}$ & Adjusted R $^{2}$ \\
\hline Quintile 1 & 0,950 & 0,902 \\
\hline Quintile 2 & 0,935 & 0,897 \\
\hline Quintile 3 & 0,967 & 0.843 \\
\hline Quintile 4 & 0.755 & 0.659 \\
\hline Quintile 5 & 0.747 & 0.459 \\
\hline Difference \{Q1- Q5 & 0,203 & 0.443 \\
p-value on Difference & $<0.001$ & $<0.001$ \\
\hline
\end{tabular}

Panel C: Regression results by quintiles of earnings level

\begin{tabular}{|l|c|c|}
\hline Quintiles by Earnings & $\beta$ (Persistence) & Adjusted R $^{2}$ \\
\hline Quintile 1 & 0.090 & 0.106 \\
\hline Quintile 2 & 0.451 & 0.414 \\
\hline Quintile 3 & 0.495 & 0.584 \\
\hline Quintile 4 & 0.520 & 0.779 \\
\hline Quintile 5 & 1.086 & 0.748 \\
\hline Difference \{Q1- Q5 & 0.996 & 0.642 \\
p-value on Difference & $<0.001$ & $<0.001$ \\
\hline
\end{tabular}

All $\beta$ (Persistence) coefficients are significant at the 0.001 level. The $p$-value for the difference in persistence coefficients across quintiles is derived from a t-test. The p-value for the difference in the Adj. R2 across quintiles is derived from a bootstrap test.

Table 3: The results of earnings volatility for long-term earnings

Panel A: Regression results for the full sample

\begin{tabular}{|l|c|c|}
\hline Prediction equations & $\boldsymbol{\beta}$ & Adjusted R $^{\mathbf{2}}$ \\
\hline Earnings $_{\mathrm{t}+1}=\alpha+\beta$ Earnings $_{\mathrm{t}}$ & 0.831 & 0.644 \\
Earnings $_{\mathrm{t}+2}=\alpha+\beta$ Earnings $_{\mathrm{t}}$ & 0.730 & 0.494 \\
Earnings $_{\mathrm{t}+3}=\alpha+\beta$ Earnings $_{\mathrm{t}}$ & 0.703 & 0.466 \\
Earnings $_{\mathrm{t}+4}=\alpha+\beta$ Earnings $_{\mathrm{t}}$ & 0.668 & 0.418 \\
Earnings $_{\mathrm{t}+5}=\alpha+\beta$ Earnings $_{\mathrm{t}}$ & 0.583 & 0.328 \\
\hline
\end{tabular}

Panel B: Regression results for the lowest earnings volatility quintile

\begin{tabular}{|l|c|c|}
\hline Prediction equations & $\beta$ & Adjusted $^{2}$ \\
\hline Earnings $_{\mathrm{t}+1}=\alpha+\beta$ Earnings $_{\mathrm{t}}$ & 0.929 & 0.897 \\
Earnings $_{\mathrm{t}+2}=\alpha+\beta$ Earnings $_{\mathrm{t}}$ & 0.882 & 0.827 \\
Earnings $_{\mathrm{t}+3}=\alpha+\beta$ Earnings $_{\mathrm{t}}$ & 0.858 & 0.804 \\
Earnings $_{\mathrm{t}+4}=\alpha+\beta$ Earnings $_{\mathrm{t}}$ & 0.860 & 0.804 \\
Earnings $_{\mathrm{t}+5}=\alpha+\beta$ Earnings $_{\mathrm{t}}$ & 0.848 & 0.787 \\
\hline
\end{tabular}

Panel C: Regression results for the highest earnings volatility quintile

\begin{tabular}{|l|c|c|}
\hline Prediction equations & $\beta$ & Adjusted R $^{2}$ \\
\hline Earning $_{\mathrm{t}+1}=\alpha+\beta$ Earnings $_{\mathrm{t}}$ & 0.839 & 0.593 \\
Earnings $_{\mathrm{t}+2}=\alpha+\beta$ Earnings $_{\mathrm{t}}$ & 0.754 & 0.458 \\
Earnings $_{\mathrm{t}+3}=\alpha+\beta$ Earnings $_{\mathrm{t}}$ & 0.755 & 0.486 \\
Earnings $_{\mathrm{t}+4}=\alpha+\beta$ Earnings $_{\mathrm{t}}$ & 0.670 & 0.421 \\
Earnings $_{\mathrm{t}+5}=\alpha+\beta$ Earnings $_{\mathrm{t}}$ & 0.523 & 0.310 \\
\hline
\end{tabular}

All $\beta$ (Persistence) coefficients are significant at the 0.001 level. 
Table 4: Distribution by firm's industries and across earnings volatility quintiles

\begin{tabular}{|l|c|c|c|c|c|c|}
\hline \multicolumn{1}{|c|}{ Industry } & Q1 & Q2 & Q3 & Q4 & Q5 & Number \\
\hline Agri-Food & - & 3 & 3 & 2 & - & 8 \\
\hline Construction & 1 & - & 2 & 1 & 1 & 5 \\
\hline Chimicals & 1 & - & - & 1 & - & 2 \\
\hline Transport and Sales & 2 & 2 & 3 & 2 & - & 9 \\
\hline Electric Industry & 3 & - & - & - & - & 3 \\
\hline Metallurgy Industry & - & 1 & - & 2 & - & 3 \\
\hline Health Care & - & - & 1 & 1 & - & 2 \\
\hline Manufacturing & - & - & - & - & 1 & 1 \\
\hline Computer services \& software & - & 1 & - & - & - & 1 \\
\hline Energy & 1 & 1 & - & - & 2 & 4 \\
\hline Real estate \& Hotel & 1 & 1 & - & 1 & - & 3 \\
\hline Information \& telecommunication & 1 & 1 & 1 & 2 & 2 & 7 \\
\hline & Total & 10 & 10 & 10 & 12 & 6 \\
\hline
\end{tabular}

